\title{
Nitritalea halalkaliphila gen. nov., sp. nov., an alkaliphilic bacterium of the family 'Cyclobacteriaceae', phylum Bacteroidetes
}

Correspondence

S. Shivaji

shivas@ccmb.res.in

\author{
P. Anil Kumar, T. N. R. Srinivas, P. Pavan Kumar, S. Madhu and S. Shivaji \\ Centre for Cellular and Molecular Biology, Uppal Road, Hyderabad - 500 007, India
}

Members of the 'Cyclobacteriaceae' have rod- or horseshoeshaped cells and have been isolated from a wide variety of habitats such as marine surface water (Brettar et al., 2004a), oilfield sediment (Ying et al., 2006), a sea urchin (Nedashkovskaya et al., 2006), alkaline groundwater, coral, marine sediments, soil enriched with boron (Nedashkovskaya et al., 2007), microbial mats from Antarctic lakes (Van Trappen et al., 2004), freshwater lakes (Liu et al., 2009), brown and green algae, tidal flat sediment (Nedashkovskaya et al., 2004), salt-water lagoons (Copa-Patiño et al., 2008), marine solar salterns (Yoon et al., 2005), sea ice (Bowman et al., 2003) and soil (Yoon et al., 2006). Lonar Lake, located in the town of Lonar, Buldhana district, Maharashtra, India $\left(19^{\circ} 58^{\prime} \mathrm{N} 76^{\circ} 30^{\prime} \mathrm{E}\right)$, is a halo-alkaline water body; several strains belonging to the Firmicutes, Proteobacteria and Actinobacteria have been isolated from the lake (Joshi et al., 2008). Indibacter alkaliphilus, a member of the family 'Cyclobacteriaceae', was recently described from Lonar Lake (Anil Kumar et al., 2010). In the present study, we describe a novel bacterium isolated from Lonar Lake that is assigned to a new genus, Nitritalea gen. nov., that also belongs to the family 'Cyclobacteriaceae'.

Strain $\mathrm{LW}^{\mathrm{T}}$ was isolated from a water sample collected from Lonar Lake on 25 August 2008. The sample that yielded strain $\mathrm{LW}^{\mathrm{T}}$ had a $\mathrm{pH}$ of 10 . For isolation of bacteria, $100 \mu \mathrm{l}$ water sample was plated on ZoBell marine

The GenBank/EMBL/DDBJ accession number for the 16S rRNA gene sequence of strain $\mathrm{LW} 7^{\top}$ is FM991866. agar medium (ZoBell, 1941) adjusted to $\mathrm{pH} 10.0$ with sodium carbonate solution $(20 \%, \mathrm{w} / \mathrm{v})$ and incubated at room temperature for 15 days. Based on the colony morphology, a dark reddish-orange-coloured colony was selected and characterized in the present study.

Cell morphology and motility were studied using a light microscope. Motility was assessed on TSA medium containing $\left(\mathrm{l}^{-1}\right) 17 \mathrm{~g}$ pancreatic casein digest, $3 \mathrm{~g}$ papaic soyabean meat digest, $5 \mathrm{~g}$ sodium chloride, $2.5 \mathrm{~g}$ dipotassium hydrogen phosphate, $2.5 \mathrm{~g}$ glucose and $0.4 \mathrm{~g}$ agar. Growth at different temperatures, salt tolerance, biochemical characteristics, carbon assimilation, $\mathrm{H}_{2} \mathrm{~S}$ production and the sensitivity of the culture to different antibiotics were determined by previously described methods (Lányí, 1987; Smibert \& Krieg, 1994). Biochemical characteristics were also double checked with the Hi25 Enterobacteriaceae identification kit (catalogue number KB003) and HiCarbohydrate kit parts A, B and C (catalogue number KB009) (both from HiMedia) according to the manufacturer's protocol. Growth of $\mathrm{LW7}^{\mathrm{T}}$ at different $\mathrm{pH}$ was checked on TSA medium buffered with citric acid/NaOH (pH 5 and 6), phosphate ( $\mathrm{pH} 7$ and 8), glycine/ $\mathrm{NaOH}$ ( $\mathrm{pH} 9$ and 10) or Tris/HCl (pH 11 and 12).

Fatty acid methyl esters were prepared and analysed by the Sherlock Microbial Identification System (MIDI) according to the protocol described by Agilent Technologies. For this purpose, strain $\mathrm{LW}^{\mathrm{T}}$ and reference strains Belliella baltica DSM $15883^{\mathrm{T}}$ and I. alkaliphilus $\mathrm{LW}^{\mathrm{T}}$ were grown 
on TSA medium at $30{ }^{\circ} \mathrm{C}$ for 2 days. Polar lipids were extracted and analysed according to the method described by Komagata \& Suzuki (1987). Menaquinones and polar lipids were determined from freeze-dried cells. Menaquinones were extracted as described by Collins et al. (1977) and analysed by HPLC (Groth et al., 1997). DNA was isolated according to the procedure of Marmur (1961) and the $G+C$ content was determined from melting point $\left(T_{\mathrm{m}}\right)$ curves (Sly et al., 1986) obtained by using a Lambda 2 UV-Vis spectrophotometer (Perkin Elmer) equipped with the Templab 2.0 software package (Perkin Elmer). DNA from Escherichia coli DH5 $\alpha$ was used as a standard in determining the $\mathrm{G}+\mathrm{C}$ content of the DNA. For $16 \mathrm{~S}$ rRNA gene sequencing, DNA was prepared using a MoBio microbial DNA isolation kit (MoBio Laboratories Inc.) and sequenced as described previously (Lane, 1991). The resultant almost-complete sequence of the $16 \mathrm{~S}$ rRNA gene contained $1502 \mathrm{nt}$. The $16 \mathrm{~S}$ rRNA gene sequence of the isolate was subjected to BLAST sequence similarity search (Altschul et al., 1990) and EzTaxon (Chun et al., 2007) to identify the nearest taxa. All 16S rRNA gene sequences belonging to members of the family 'Cyclobacteriaceae' were downloaded from the NCBI database (http://www.ncbi.nlm.nih.gov) and aligned using the CLUSTAL_X program (Thompson et al., 1997) and the alignment was corrected manually. Phylogenetic trees were constructed using the maximum-likelihood algorithm using the PhyML program (Guindon \& Gascuel, 2003) and the neighbour-joining method (Saitou \& Nei, 1987) using the PHYLIP package, version 3.5 (Felsenstein, 1993), and the resultant tree topologies were evaluated by bootstrap analysis based on 1000 resamplings using the SEQBOOT and CONSENSE programs in the PHYLIP package. Pairwise evolutionary distances were computed using the

Table 1. Fatty acid compositions of strain $L W 7^{\top}$ and closely related members of the family 'Cyclobacteriaceae'

Strains: $1, \mathrm{LW}^{\mathrm{T}} ; 2$, B. baltica DSM $15883^{\mathrm{T}} ; 3$, I. alkaliphilus $\mathrm{LW} 1^{\mathrm{T}}$. Results are percentages of total fatty acids; fatty acids amounting to $5 \%$ or more of the total are in bold. Data for all strains are from the present study, and were obtained from cultures grown on TSA at $30{ }^{\circ} \mathrm{C}$ for $48 \mathrm{~h}$. - , Not detected; tr, trace $(<1 \%)$.

\begin{tabular}{|c|c|c|c|}
\hline Fatty acid & 1 & 2 & 3 \\
\hline $\mathrm{C}_{14: 0}$ & $\operatorname{tr}$ & - & - \\
\hline iso- $\mathrm{C}_{14: 0}$ & $\operatorname{tr}$ & - & - \\
\hline iso- $\mathrm{C}_{15: 1} \mathrm{G}$ & - & 8.7 & - \\
\hline iso- $\mathrm{C}_{15: 0}$ & 59.6 & 21.1 & 47.0 \\
\hline anteiso- $\mathrm{C}_{15: 0}$ & 3.1 & 3.8 & 7.6 \\
\hline $\mathrm{C}_{15: 0} 3-\mathrm{OH}$ & - & 2.1 & 3.7 \\
\hline iso- $\mathrm{C}_{15: 0} 3-\mathrm{OH}$ & 2.1 & 2.9 & 2.1 \\
\hline $\mathrm{C}_{15: 1} \omega 6 c$ & 1.6 & - & - \\
\hline $\mathrm{C}_{16: 0}$ & 1.2 & 6.0 & 3.5 \\
\hline iso- $\mathrm{C}_{16: 0}$ & 1.8 & 2.9 & 2.3 \\
\hline $\mathrm{C}_{16: 0} 3-\mathrm{OH}$ & - & 1.6 & - \\
\hline iso- $\mathrm{C}_{16: 0} 3-\mathrm{OH}$ & $\operatorname{tr}$ & - & - \\
\hline iso- $\mathrm{C}_{16: 1} \mathrm{H}$ & $\operatorname{tr}$ & - & - \\
\hline $\mathrm{C}_{16: 1} \omega 5 c$ & 2.4 & 8.9 & - \\
\hline $\mathrm{C}_{17: 0} 2-\mathrm{OH}$ & - & - & - \\
\hline iso- $\mathrm{C}_{17: 0}$ & 1.4 & 1.8 & 3.5 \\
\hline anteiso- $\mathrm{C}_{17: 0}$ & $\operatorname{tr}$ & - & - \\
\hline iso- $\mathrm{C}_{17: 0} 3-\mathrm{OH}$ & 8.9 & 6.5 & 8.2 \\
\hline $\mathrm{C}_{17: 1} \omega 6 c$ & 1.4 & 4.0 & - \\
\hline iso- $\mathrm{C}_{17: 1} \omega 9 c$ & - & 9.5 & 17.6 \\
\hline anteiso- $C_{17: 1} \omega 9 c$ & - & - & - \\
\hline $\mathrm{C}_{18: 0}$ & - & - & - \\
\hline iso- $\mathrm{C}_{18: 0}$ & 1.5 & - & - \\
\hline iso- $\mathrm{C}_{19: 0}$ & $\operatorname{tr}$ & - & - \\
\hline Summed feature $3^{\star}$ & 3.7 & 20.2 & 3.3 \\
\hline Summed feature $4^{\star}$ & 1.4 & - & - \\
\hline Summed feature $9^{*}$ & 2.7 & - & - \\
\hline
\end{tabular}

${ }^{*}$ Summed features are groups of two or three fatty acids that could not be separated by the MIDI system. Summed feature 3 contained iso- $\mathrm{C}_{15: 0} 2-\mathrm{OH}$ and/or $\mathrm{C}_{16: 1} \omega 7 c$; summed feature 4 contained iso- $\mathrm{C}_{17: 1} \mathrm{I}$ and/or anteiso- $\mathrm{C}_{17: 1} \mathrm{~B}$; summed feature 9 contained iso- $\mathrm{C}_{17: 1} \omega 9 \mathrm{c}$ and/or 10-methyl $\mathrm{C}_{16: 0}$. 
DNADIST program with Kimura's two-parameter model (Kimura, 1980).

Cells of strain $\mathrm{LW}^{\mathrm{T}}$ were rods, $0.7-0.8 \mu \mathrm{m}$ wide and 2$3 \mu \mathrm{m}$ long, and multiplied by binary fission. Cells stained Gram-negative and were non-motile. Colonies were circular, 2-3 $\mathrm{mm}$ in diameter, smooth, dark reddish orange, opaque, convex and entire on half-strength marine agar. The strain grew aerobically and chemoheterotrophically. Growth was observed at $25-40{ }^{\circ} \mathrm{C}$, with optimum growth at $37{ }^{\circ} \mathrm{C}$. Growth was observed at $1-22 \% \mathrm{NaCl}(\mathrm{w} /$ v), with optimum growth between 2 and $5 \% \mathrm{NaCl}(\mathrm{w} / \mathrm{v})$, and at $\mathrm{pH}$ 7.5-12, with optimum growth at $\mathrm{pH} 10$. The spectrum of the ethanol extract of strain $\mathrm{LW}^{\mathrm{T}}$ showed a broad peak with a maximum around $480 \mathrm{~nm}$ that is typical of carotenoids. Alkalinization did not show a bathochromic shift of the peaks. Therefore, it was concluded that strain $\mathrm{LW}^{\mathrm{T}}$ contains carotenoids but no flexirubins, as often observed for marine bacteria belonging to the Bacteroidetes (Brettar et al., 2004a). The cellular fatty acid composition of strain $\mathrm{LW}^{\mathrm{T}}$ showed a spectrum of 20 fatty acids, with a pronounced dominance of the saturated fatty acid iso- $\mathrm{C}_{15: 0}$ (Table 1). The saturated fatty acids constituted $85.6 \%$ of the total, with iso- $\mathrm{C}_{15: 0}$ forming the major fraction $(59.6 \%)$. When compared with $B$. baltica DSM $15883^{\mathrm{T}}$, the number of fatty acids detected in strain $\mathrm{LW}^{\mathrm{T}}$ was higher and the composition differed considerably (Table 1). The menaquinones present in $\mathrm{LW}^{\mathrm{T}}$ were MK-4 (36.3\%) and MK-5 (63.7\%), and the phospholipids were phosphatidylglycerol and phosphatidylethanolamine. The other characteristics of $\mathrm{LW}^{\mathrm{T}}$ are listed in the species description. The DNA G $+\mathrm{C}$ content of strain $\mathrm{LW7}^{\mathrm{T}}$ was $49 \mathrm{~mol} \%$.

The phylogenetic relationship of strain $\mathrm{LW}^{\mathrm{T}}$ was ascertained based on $16 \mathrm{~S}$ rRNA gene sequence similarity to other reported sequences using BLAST sequence similarity search (NCBI BLAST/EzTaxon). The results indicated that, at the $16 \mathrm{~S}$ rRNA gene sequence level, strain $L W 7^{\mathrm{T}}$ was close to B. baltica $\mathrm{BA} 134^{\mathrm{T}}$, with a pairwise similarity of $94 \%$. The BLAST results indicated that strain $L W 7^{\mathrm{T}}$ probably belongs to a new genus. Phylogenetic analyses based on maximum-likelihood and neighbour-joining trees further indicated that strain $\mathrm{LW}^{\mathrm{T}}$ clustered with $B$. baltica, at a phylogenetic distance of $92.5 \%$, and distinct from the clades represented by the genera Algoriphagus, Aquiflexum, Cyclobacterium, Echinicola and Indibacter (Fig. 1).

Strain $L W 7^{\mathrm{T}}$ could also be differentiated phenotypically from the closely related species B. baltica (Brettar et al., 2004a) (Table 2). For instance, $L W 7^{\mathrm{T}}$ differs from B. baltica $\mathrm{BA} 134^{\mathrm{T}}$ with respect to colony colour, cell size, optimal salt concentration for growth, salt tolerance, growth at $\mathrm{pH} 12$ and DNA $\mathrm{G}+\mathrm{C}$ content (Table 2). In addition, $\mathrm{LW7}^{\mathrm{T}}$ shows specific differences from $B$. baltica $\mathrm{BA} 134^{\mathrm{T}}$ with respect to acid production and utilization of various carbon sources. I. alkaliphilus, a member of the family 'Cyclobacteriaceae', was described from the same source as strain $\mathrm{LW}^{\mathrm{T}}$ (Anil Kumar et al., 2010), although at a different depth. Strain $L W 7^{\mathrm{T}}$ differed from I. alkaliphilus phylogenetically (strain $L W 7^{\mathrm{T}}$ clustered with $B$. baltica but I. alkaliphilus forms a separate clade from this cluster; Fig. 1), phenotypically (nitrate reduction, salinity range, hydrolysis of gelatin and starch, acid production and substrate utilization; Table 2) and chemotaxonomically (DNA G $+\mathrm{C}$ content and fatty acid composition; Tables 1 and 2). Thus, the cumulative differences that strain $\mathrm{LW} 7^{\mathrm{T}}$ exhibits from these closely related species unambiguously support the creation of a new genus and species, for which the name Nitritalea halalkaliphila gen. nov., sp. nov. is proposed.

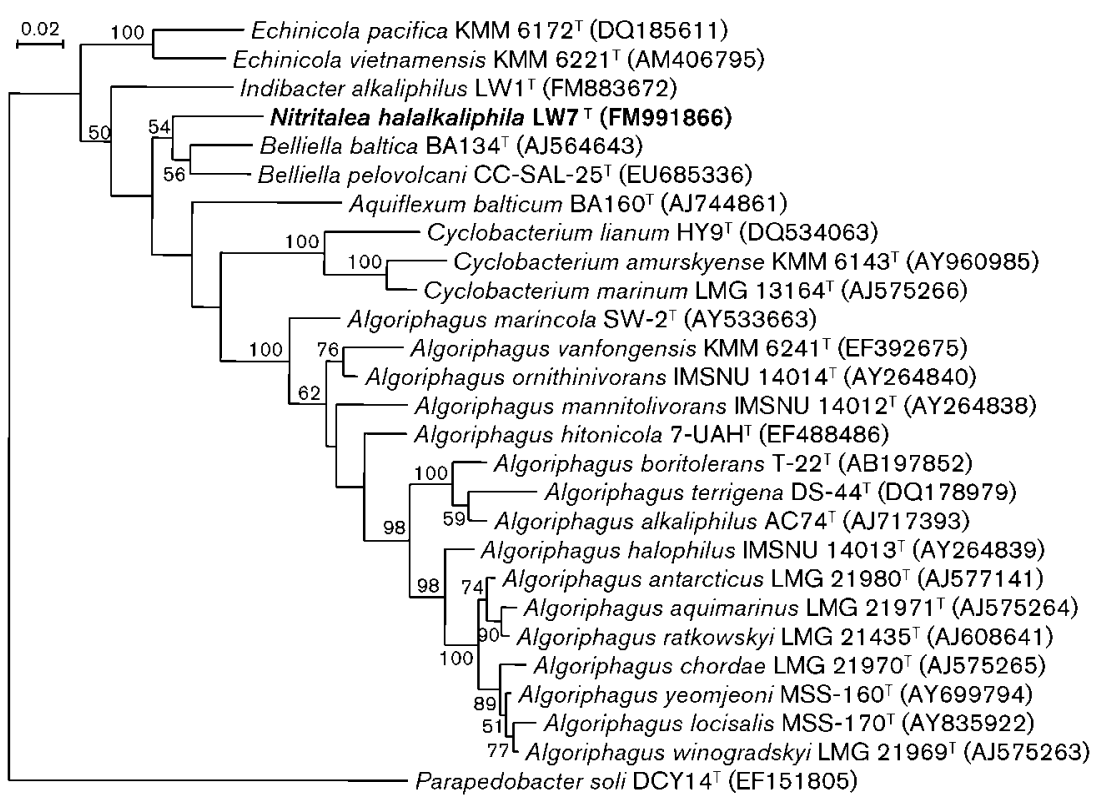

Fig. 1. Phylogenetic tree based on 16S rRNA gene sequences showing the relationship of strain $\mathrm{LW7}^{\top}$ with members of the 'Cyclobacteriaceae'. The tree was constructed using the maximum-likelihood method. Numbers at nodes are bootstrap percentages. Bar, 0.02 substitutions per alignment position. 


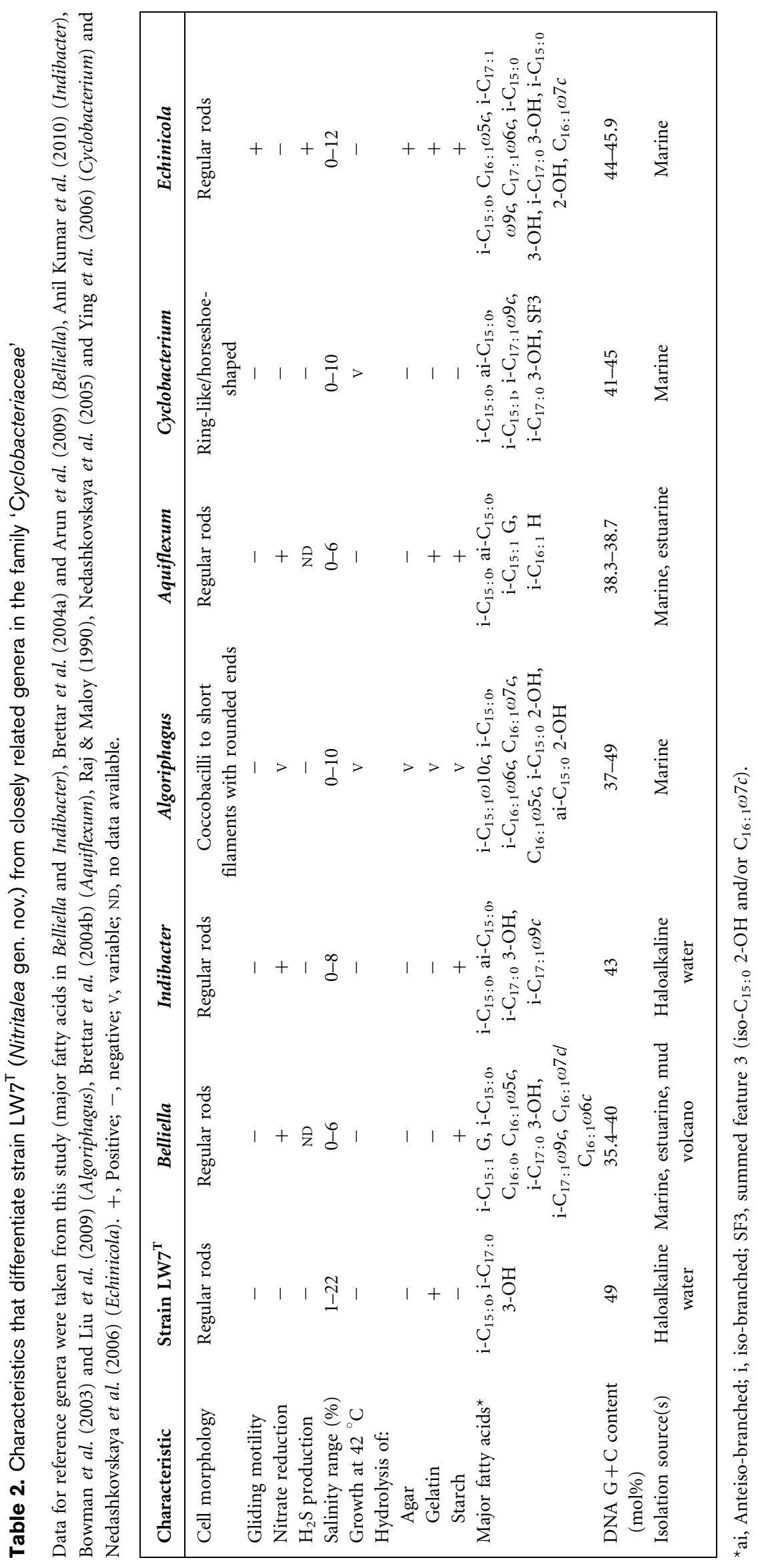




\section{Description of Nitritalea gen. nov.}

Nitritalea (Ni.tri.ta'le.a. L. n. nitrum natural soda; L. fem. n. talea a rod, a stick; N.L. fem. n. Nitritalea a rod or stick from natural soda, referring to the isolation of the first strain from a soda lake).

Cells stain Gram-negative and are aerobic rods. Positive for catalase, oxidase and gelatinase and negative for amylase, lipase and urease. The major fatty acids are iso- $\mathrm{C}_{15: 0}$ and iso- $\mathrm{C}_{17: 0} 3-\mathrm{OH}$ and $\mathrm{MK}-4$ and $\mathrm{MK}-5$ are the predominant respiratory quinones. The phospholipids include phosphatidylglycerol and phosphatidylethanolamine. The genus is affiliated to the family 'Cyclobacteriaceae' of the order 'Sphingobacteriales' of class 'Sphingobacteria'. The type species is Nitritalea halalkaliphila.

\section{Description of Nitritalea halalkaliphila sp. nov.}

Nitritalea halalkaliphila (hal.al'ka.li.phi'la. Gr. n. hals, halos salt; N.L. n. alkali alkali; N.L. fem. adj. phila from Gr. fem. adj. phile friendly to, loving; N.L. fem. adj. halalkaliphila loving salt and alkaline conditions).

Displays the properties described for the genus as well as the following properties. Cells are $0.7-0.8 \mu \mathrm{m}$ wide and $2-$ $3 \mu \mathrm{m}$ long, occur singly and multiply by binary fission. Colonies on half-strength marine agar are circular, 2$3 \mathrm{~mm}$ in diameter, smooth, dark reddish orange, opaque, convex and entire. Grows at $25-40{ }^{\circ} \mathrm{C}$ with optimum growth at $37{ }^{\circ} \mathrm{C}$ and tolerates up to $22.0 \% \mathrm{NaCl}(\mathrm{w} / \mathrm{v})$. Growth occurs at $\mathrm{pH} 7.5-12.0$. Tests for ornithine decarboxylase and lysine decarboxylase are positive; tests for $\beta$-galactosidase, arginine dihydrolase and phenylalanine deaminase are negative. The methyl red and VogesProskauer reactions are negative. Gelatin is hydrolysed but starch, Tween 60 and aesculin are not. Nitrate is not reduced to nitrite and $\mathrm{H}_{2} \mathrm{~S}$ gas is not produced. Produces acid from sucrose, glucose, sorbitol, cellobiose, inositol, Dfructose, mannose, dulcitol, inulin and melibiose but not from xylose, erythritol, raffinose, methyl $\alpha$-D-glucoside, arabinose, maltose, amygdalin, galactose, mannitol, glycogen, ribose, inositol, sorbose, mannoside or aesculin, even after 1 week of incubation at optimum temperature and $\mathrm{pH}$. Assimilates pyruvic acid, succinic acid, citrate, sucrose, lactose, fructose, glucose, raffinose, trehalose, melibiose, sucrose, mannose, inulin, dulcitol, inositol, cellobiose, $o$-nitrophenyl $\beta$-galactoside, malonate, isoleucine, DL-aspartic acid, L-valine, L-histidine, glutamine and glutamic acid but not acetate, aesculin, xylose, maltose, galactose, L-arabinose, sodium gluconate, glycerol, salicin, glucosamine, sorbitol, mannitol, adonitol, methyl $\alpha$-Dglucoside, ribose, rhamnose, melezitose, methyl $\alpha$-Dmannoside, xylitol, D-arabinose, sorbose, L-proline, phenylalanine, L-arginine, threonine, L-tyrosine, L-serine, leucine, L-methionine or D-gluconic acid. Susceptible to ( $\mu \mathrm{g}$ per disc unless indicated) amikacin (30), ampicillin (10), colistin (10), cefuroxime (30), norfloxacin (10), erythromycin (15), novobiocin (30), cefoperazone (75), streptomycin (10), ciprofloxacin (5), gentamicin-G (30), cefazolin (30), nitrofurantoin (300), carbenicillin (100), penicillin G (10), lomefloxacin (30), co-trimoxazole (25), tetracycline (30), rifampicin (30), chloramphenicol (30), bacitracin (10), roxithromycin (30), polymixin B (50 U), lincomycin (2) and vancomycin (30) and resistant to kanamycin (30), nalidixic acid (30) and tobramycin (10). The cellular fatty acid composition of the type strain is detailed in Table 1. The genomic DNA G $+\mathrm{C}$ content of the type strain is $49 \mathrm{~mol} \%$.

The type strain, $\mathrm{LW7}^{\mathrm{T}}$ (=CCUG $57665^{\mathrm{T}}=\mathrm{JCM} 15946^{\mathrm{T}}$ $=$ NCCB $100279^{\mathrm{T}}$ ), was isolated from a water sample collected at a depth of $4.5 \mathrm{~m}$ from Lonar Lake, Lonar, Buldhana district, Maharashtra, India.

\section{Acknowledgements}

We would like to thank Dr S. W. A. Naqvi, Scientist, National Institute of Oceanography, Goa, India, for providing the samples. S. S. is thankful to the National Centre for Antarctic and Ocean Research, Goa, Department of Biotechnology, New Delhi, and the CSIR Network Project on Biodiversity for funding. T. N. R. S. acknowledges the CSIR, Government of India, for the award of a Research Associateship.

\section{References}

Altschul, S. F., Gish, W., Miller, W., Myers, E. W. \& Lipman, D. J. (1990). Basic local alignment search tool. J Mol Biol 215, 403-410.

Anil Kumar, P., Srinivas, T. N. R., Madhu, S., Ruth Manorama, R. \& Shivaji, S. (2010). Indibacter alkaliphilus gen. nov., sp. nov., an alkaliphilic bacterium isolated from a haloalkaline lake. Int J Syst Evol Microbiol 60, 721-726.

Arun, A. B., Young, C. C., Chen, W. M., Hung, M. H., Lai, W. A., Chou, J. H., Rekha, P. D., Shen, F. T. \& Su, S. P. (2009). Belliella pelovolcani sp. nov., isolated from a mud-volcano in Taiwan. Int J Syst Evol Microbiol 59, 2534-2537.

Bowman, J. P., Nichols, C. M. \& Gibson, J. A. (2003). Algoriphagus ratkowskyi gen. nov., sp. nov., Brumimicrobium glaciale gen. nov., sp. nov., Cryomorpha ignava gen. nov., sp. nov. and Crocinitomix catalasitica gen. nov., sp. nov., novel flavobacteria isolated from various polar habitats. Int J Syst Evol Microbiol 53, 1343-1355.

Brettar, I., Christen, R. \& Höfle, M. G. (2004a). Belliella baltica gen. nov., sp. nov., a novel marine bacterium of the CytophagaFlavobacterium-Bacteroides group isolated from surface water of the central Baltic Sea. Int J Syst Evol Microbiol 54, 65-70.

Brettar, I., Christen, R. \& Höfle, M. G. (2004b). Aquiflexum balticum gen. nov., sp. nov., a novel marine bacterium of the CytophagaFlavobacterium-Bacteroides group isolated from surface water of the central Baltic Sea. Int J Syst Evol Microbiol 54, 2335-2341.

Chun, J., Lee, J.-H., Jung, Y., Kim, M., Kim, S., Kim, B. K. \& Lim, Y. W. (2007). EzTaxon: a web-based tool for the identification of prokaryotes based on $16 \mathrm{~S}$ ribosomal RNA gene sequences. Int J Syst Evol Microbiol 57, 2259-2261.

Collins, M. D., Pirouz, T., Goodfellow, M. \& Minnikin, D. E. (1977). Distribution of menaquinones in actinomycetes and corynebacteria. J Gen Microbiol 100, 221-230.

Copa-Patiño, J. L., Arenas, M., Soliveri, J., Sánchez-Porro, C. \& Ventosa, A. (2008). Algoriphagus hitonicola sp. nov., isolated from an athalassohaline lagoon. Int J Syst Evol Microbiol 58, 424-428. 
Felsenstein, J. (1993). PHYLIP (phylogeny inference package) version 3.5.1. Distributed by the author. Department of Genome Sciences, University of Washington, Seattle, USA.

Groth, I., Schumann, P., Rainey, F. A., Martin, K., Schuetze, B. \& Augsten, K. (1997). Demetria terragena gen. nov., sp. nov., a new genus of actinomycetes isolated from compost soil. Int J Syst Bacteriol 47, 1129-1133.

Guindon, S. \& Gascuel, O. (2003). A simple, fast, and accurate algorithm to estimate large phylogenies by maximum likelihood. Syst Biol 52, 696-704.

Joshi, A. A., Kanekar, P. P., Kelkar, A. S., Shouche, Y. S., Vani, A. A., Borgave, S. B. \& Sarnaik, S. S. (2008). Cultivable bacterial diversity of alkaline Lonar lake, India. Microb Ecol 55, 163-172.

Kimura, M. (1980). A simple method for estimating evolutionary rates of base substitutions through comparative studies of nucleotide sequences. J Mol Evol 16, 111-120.

Komagata, K. \& Suzuki, K. (1987). Lipid and cell-wall analysis in bacterial systematics. Methods Microbiol 19, 161-207.

Lane, D. J. (1991). 16S/23S rRNA sequencing. In Nucleic Acid Techniques in Bacterial Systematics, pp. 115-175. Edited by E. Stackebrandt \& M. Goodfellow. Chichester: Wiley.

Lányí, B. (1987). Classical and rapid identification methods for medically important bacteria. Methods Microbiol 19, 1-67.

Liu, Y., Li, H., Jiang, J. T., Liu, Y. H., Song, X. F., Xu, C. J. \& Liu, Z. P. (2009). Algoriphagus aquatilis sp. nov., isolated from a freshwater lake. Int J Syst Evol Microbiol 59, 1759-1763.

Marmur, J. (1961). A procedure for the isolation of deoxyribonucleic acid from microorganisms. J Mol Biol 3, 208-218.

Nedashkovskaya, O. I., Vancanneyt, M., Van Trappen, S. Vandemeulebroecke, K., Lysenko, A. M., Rohde, M., Falsen, E., Frolova, G. M., Mikhailov, V. V. \& Swings, J. (2004). Description of Algoriphagus aquimarinus sp. nov., Algoriphagus chordae sp. nov. and Algoriphagus winogradskyi sp. nov., from sea water and algae, transfer of Hongiella halophila Yi and Chun 2004 to the genus Algoriphagus as Algoriphagus halophilus comb. nov. and emended descriptions of the genera Algoriphagus Bowman et al. 2003 and Hongiella Yi and Chun 2004. Int J Syst Evol Microbiol 54, 1757-1764.

Nedashkovskaya, O. I., Kim, S. B., Lee, M. S., Park, M. S., Lee, K. H., Lysenko, A. M., Oh, H. W., Mikhailov, V. V. \& Bae, K. S. (2005). Cyclobacterium amurskyense sp. nov., a novel marine bacterium isolated from sea water. Int J Syst Evol Microbiol 55, 2391-2394.

Nedashkovskaya, O. I., Kim, S. B., Vancanneyt, M., Lysenko, A. M., Shin, D. S., Park, M. S., Lee, K. H., Jung, W. J., Kalinovskaya, N. I. \& other authors (2006). Echinicola pacifica gen. nov., sp. nov., a novel flexibacterium isolated from the sea urchin Strongylocentrotus intermedius. Int J Syst Evol Microbiol 56, 953-958.

Nedashkovskaya, O. I., Kim, S. B., Kwon, K. K., Shin, D. S., Luo, X., Kim, S. J. \& Mikhailov, V. V. (2007). Proposal of Algoriphagus vanfongensis sp. nov., transfer of members of the genera Hongiella Yi and Chun 2004 emend. Nedashkovskaya et al. 2004 and Chimaereicella Tiago et al. 2006 to the genus Algoriphagus, and emended description of the genus Algoriphagus Bowman et al. 2003 emend. Nedashkovskaya et al. 2004. Int J Syst Evol Microbiol 57, 19881994.

Raj, H. D. \& Maloy, S. R. (1990). Proposal of Cyclobacterium marinus gen. nov., comb. nov., for a marine bacterium previously assigned to the genus Flectobacillus. Int J Syst Bacteriol 40, 337-347.

Saitou, N. \& Nei, M. (1987). The neighbor-joining method: a new method for reconstructing phylogenetic trees. Mol Biol Evol 4, 406425.

Sly, L. I., Blackall, L. L., Kraat, P. C., Tao, T.-S. \& Sangkhobol, V. (1986). The use of second derivative plots for the determination of mol\% guanine plus cytosine of DNA by the thermal denaturation method. J Microbiol Methods 5, 139-156.

Smibert, R. M. \& Krieg, N. R. (1994). Phenotypic characterization. In Methods for General and Molecular Bacteriology, pp. 607-654. Edited by P. Gerhardt, R. G. E. Murray, W. A. Wood \& N. R. Krieg. Washington, DC: American Society for Microbiology.

Thompson, J. D., Higgins, D. G., Gibson, T. J., Plewniak, F., Jeanmougin, F. \& Higgins, D. G. (1997). The CLUSTAL_X windows interface: flexible strategies for multiple sequence alignment aided by quality analysis tools. Nucleic Acids Res 25, 4876-4882.

Van Trappen, S., Vandecandelaere, I., Mergaert, J. \& Swings, J. (2004). Algoriphagus antarcticus sp. nov., a novel psychrophile from microbial mats in Antarctic lakes. Int J Syst Evol Microbiol 54, 19691973.

Ying, J. Y., Wang, B. J., Yang, S. S. \& Liu, S. J. (2006). Cyclobacterium lianum sp. nov., a marine bacterium isolated from sediment of an oilfield in the South China Sea, and emended description of the genus Cyclobacterium. Int J Syst Evol Microbiol 56, 2927-2930.

Yoon, J. H., Kang, S. J. \& Oh, T. K. (2005). Algoriphagus locisalis sp. nov., isolated from a marine solar saltern. Int J Syst Evol Microbiol 55, 1635-1639.

Yoon, J. H., Lee, M. H., Kang, S. J. \& Oh, T. K. (2006). Algoriphagus terrigena sp. nov., isolated from soil. Int J Syst Evol Microbiol 56, 777780.

ZoBell, C. E. (1941). Studies on marine bacteria. I. The cultural requirements of heterotrophic aerobes. J Mar Res 4, 42-75. 